\title{
How Two Different Cenozoic Geologic and Glacial History Paradigms Explain the Southcentral Montana Musselshell-Yellowstone River Drainage Divide Origin, USA
}

\author{
Eric Clausen \\ Independent Investigator, 100 West Ave D-17, Jenkintown, PA 19046, USA. E-mail: eric2clausen@gmail.com
}

Received: May 8, 2021

doi:10.5539/esr.v10n2p42

\author{
Accepted: June 2, $2021 \quad$ Online Published: June 15, 2021 \\ URL: https://doi.org/10.5539/esr.v10n2p42
}

\begin{abstract}
The accepted Cenozoic geologic and glacial history paradigm (accepted paradigm) considers the southcentral Montana Musselshell-Yellowstone River drainage divide to have originated during Tertiary (or preglacial) time while a new and different Cenozoic geologic and glacial history paradigm (new paradigm) describes how headward erosion of a northeastoriented Musselshell River valley segment captured huge southeast-oriented meltwater floods to create the drainage divide late during a continental ice sheet's melt history. Northwest to southeast oriented divide crossings (low points observed on detailed topographic maps where water once flowed across the drainage divide), southeast-oriented Yellowstone and Musselshell River segments immediately upstream from northeast-oriented Yellowstone and Musselshell River segments, and southeast- and northwest-oriented tributaries to northeast-oriented Yellowstone and Musselshell River segments indicate a major southeast-oriented drainage system predated the northeast-oriented Yellowstone and Musselshell River segments. Closeness of the divide crossings, divide crossing floor elevations, large escarpment-surrounded erosional amphitheater-shaped basins, and unusual flat-floored internally drained basin areas (straddling the drainage divide), all suggest the previous southeast-oriented drainage system moved large quantities of water which deeply eroded the region. In the mid- $20^{\text {th }}$ century geomorphologists working from the accepted paradigm perspective determined trying to explain such erosional landform evidence from the accepted paradigm perspective was a nonproductive research activity and now rarely investigate erosional landform origins. On the other hand, the new paradigm appears to explain most, if not all observed erosional landform features, although the two paradigms lead to significantly different regional Cenozoic geologic and glacial histories that cannot be easily compared.
\end{abstract}

Keywords: Comanche Basin, Dunn Mountain, Hoskins Basin, Ice-marginal Meltwater Floods, Lake Basin, Missouri River Drainage Basin

\section{Introduction}

\subsection{Statement of the Problem}

Scientific paradigms according to Thomas Kuhn (1970) are the seldom challenged rules and assumptions which researchers in various scientific disciplines use to find and explain evidence. In other words, paradigms define what research questions scientists should seek to answer and also describe how answers to those questions should be sought. Scientific paradigm rules and assumptions are selected and changed based on their ability to explain evidence and to identify research opportunities, although paradigms also identify anomalous evidence a scientific discipline's accepted paradigm cannot satisfactorily explain. According to Kuhn anomalous evidence does not necessarily falsify a scientific paradigm because future paradigm tweaking or research may provide explanations without requiring a paradigm rejection. However, when large amounts of anomalous evidence pile up and researchers have given up on trying to explain that unexplained evidence Kuhn suggests a new paradigm may emerge, which can lead to a battle over which of two competing paradigms the scientific discipline should use.

At what point should unexplained evidence be considered anomalous evidence an accepted paradigm cannot satisfactorily explain? For example, this paper's southcentral Montana Musselshell-Yellowstone River drainage divide study region (identified in figure 1 and shown in detail in figure 2) contains yet to be addressed drainage and erosional landform features including the drainage divide itself, significant Yellowstone and Musselshell River direction changes, and large escarpment-surrounded amphitheater-shaped basins. These are large-scale erosional landforms deserving of the geomorphology research community's attention, but to date many of these features have yet to be satisfactorily explained. The author of this paper, Clausen (2020), suggested the accepted Cenozoic geologic and glacial history paradigm 
(accepted paradigm) prevents researchers from addressing such large-scale erosional landform origins and proposed an alternative paradigm (new paradigm) which he claims can explain most Missouri River drainage basin large-scale erosional landform features. The study reported here uses detailed topographic maps to explore how the accepted and new paradigms each explain large-scale Musselshell-Yellowstone River drainage divide area erosional features.

\subsection{Geographic Setting}

The Musselshell-Yellowstone River drainage divide area study region (identified in figure 1) is located in southcentral Montana and is crossed by roughly parallel southeast- and northeast-oriented Musselshell and Yellowstone River segments. Upstream from the study region the Yellowstone River originates in northwest Wyoming mountains and flows across the high elevation Yellowstone Plateau in north and northwest directions before turning in a northeast and then southeast direction to enter the study region and then after turning in a northeast direction the Yellowstone River continues to flow in a northeast direction to join the Missouri River (at the Montana-North Dakota border). The Musselshell River originates in Montana mountains and flows in a southeast direction to enter the identified study region where it turns in a northeast direction and immediately after leaving the figure 2 map area turns in a north direction to join the Missouri River. Figure 2 provides a detailed view of the identified study region with the regional drainage pattern and MusselshellYellowstone River drainage divide location superimposed on satellite imagery. Interestingly, most tributaries to the northeast-oriented segments of both the Musselshell and Yellowstone Rivers are oriented in either southeast or northwest directions and in the east half of figure 2 southeast-oriented tributaries flowing to the Yellowstone River are longer than northwest-oriented tributaries flowing to the Musselshell River.

\subsection{Previous Work-Accepted Paradigm}

Most previous work related to study region landforms dates back to the early 1900s and much of that work emphasized economic geology and only briefly described regional landforms with the landform origins being more rarely discussed. For example, Woolsey et al (1917) in a report on the Bull Mountain coal field (located in darker colored areas surrounding the northeast-oriented Musselshell River segment in figure 2) include several paragraphs describing the regional topography and drainage, but do not address most larger-scale landform origins. Ellis and Meinzer (1924, p. 4-5) who focused on ground water resources include a more detailed regional geomorphology discussion and observe the Bull Mountain Upland consists "of a group of mesas that have been brought into relief by the erosion of the plains of which they were formerly a part. Their tops are flat table-lands bordered by steep slopes and cliffs, in which may be seen the edges of the layers of sandstone and shale which underlie the tablelands and which formerly covered the entire region but have now been eroded from the surrounding country."

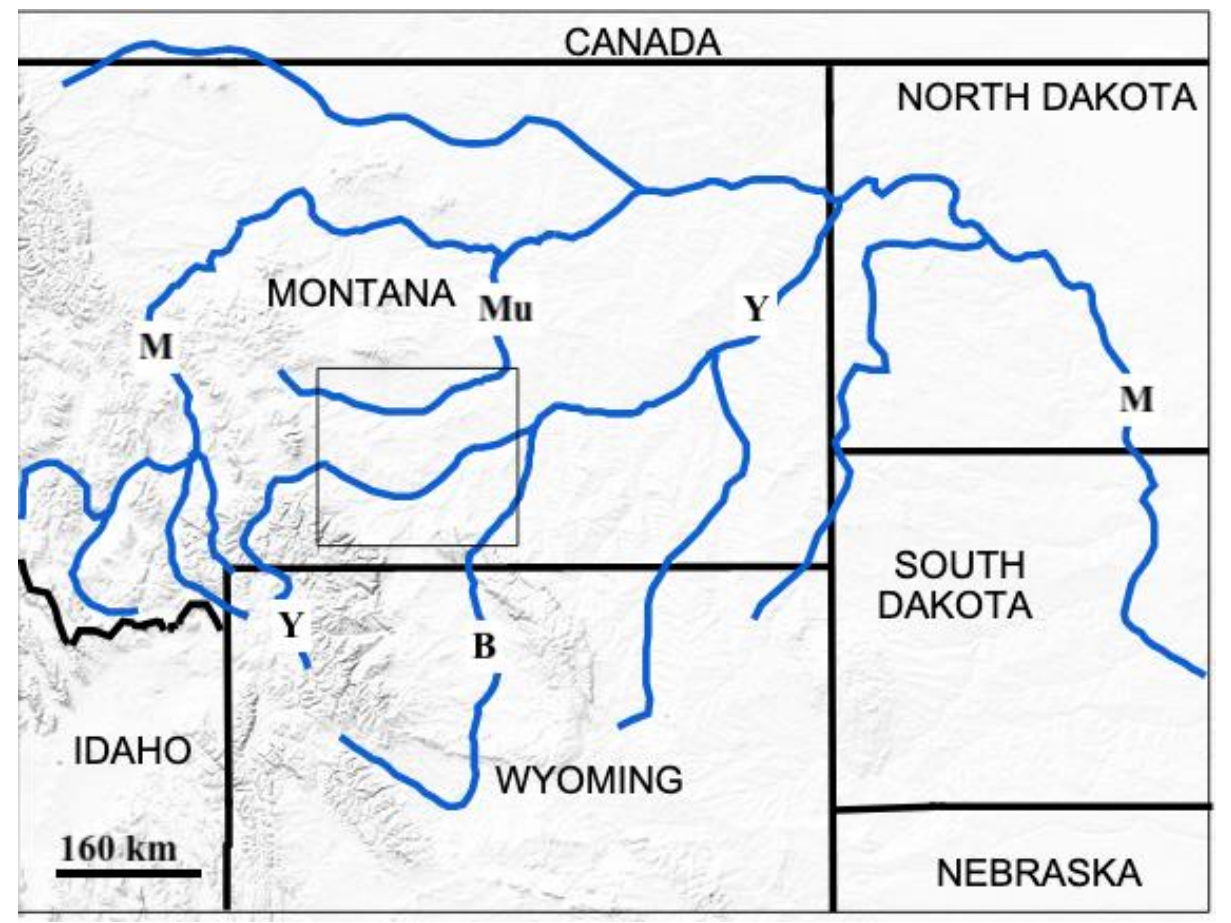

Figure 1. Modified map from United States Geological Survey (USGS) National Map website showing Musselshell (Mu), Bighorn (B), Yellowstone (Y), and Missouri (M) River routes relative to the study region (identified by rectangle and shown in detail in figure 2). 
In the region surrounding the Bull Mountains Ellis and Meinzer suggest "The present surface is apparently the product of several cycles of erosion, in each of which the streams cut down to a lower level" and then add "The streams follow courses without much regard to the structure of the rocks or the present topography... These are in part antecedent streams. Where they flow over anticlines they have cut into the rocks as fast as the rocks were bowed up." Ellis and Meinzer (p. 6) use a quote from Bowen (1919) to argue the area was first "beveled to a surface corresponding roughly to the tops of the ridges and buttes; later this surface was dissected producing the present lowlands." The Bowen quote also describes terrace gravels, which occur at several levels, but which are "most prominent at the tops of the highest buttes and ridges. The detached areas rise to about the same elevation, so that if the surface represented by them were restored it would form a plain rising gradually toward the mountains" (to the west).

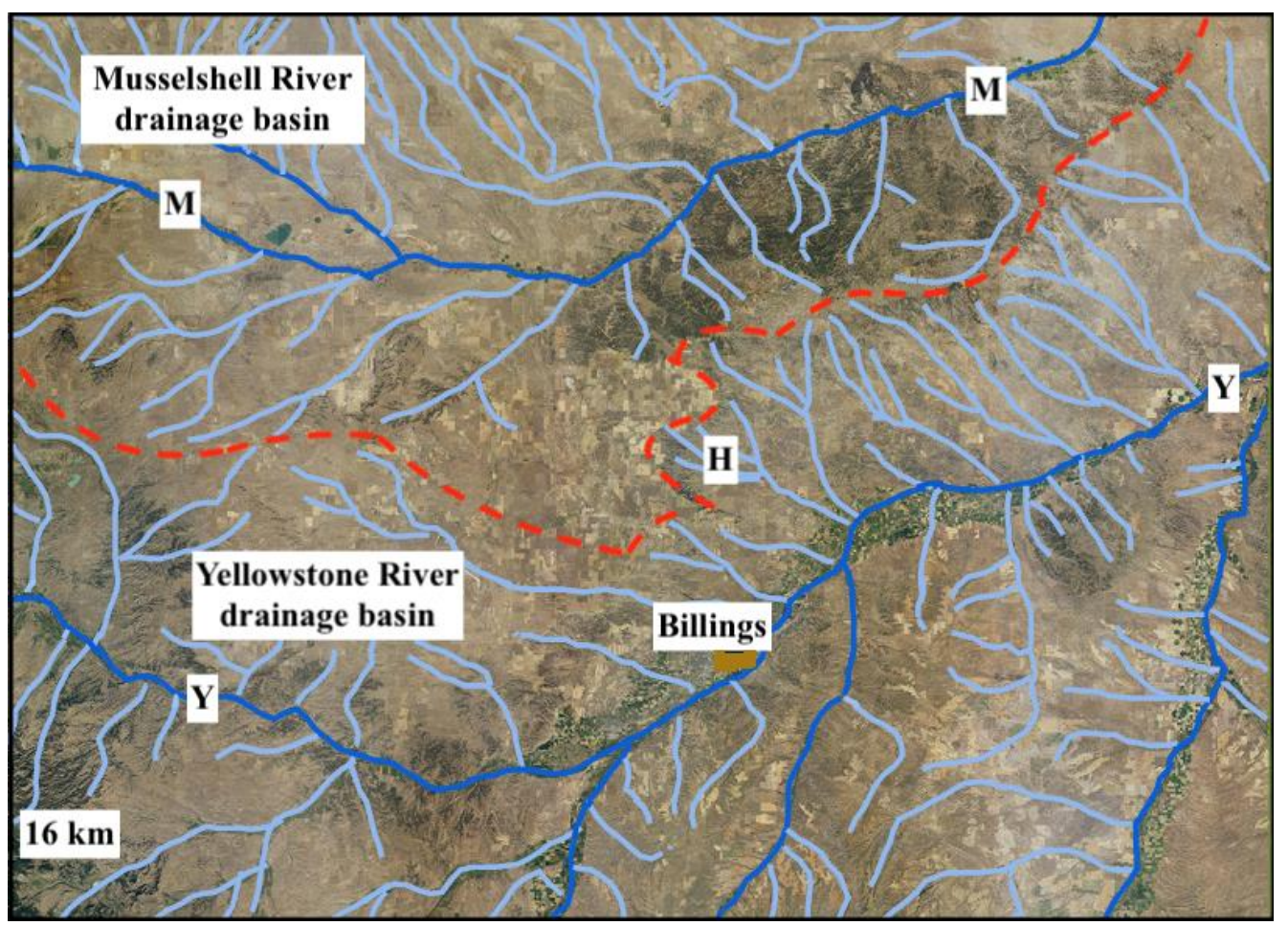

Figure 2. Modified imagery from USGS National Map website showing southcentral Montana drainage routes and the Musselshell-Yellowstone River drainage divide (red dashed line) in relation to Musselshell River (M), Yellowstone River (Y), Billings, and Hoskins Basin (H).

Continuing in their discussion of the regional physiography Ells and Meinzer (p. 7) expand on previous descriptions made by Hancock (1918), who had been investigating the regional oil and gas potential, by describing "a number of undrained or imperfectly drained basins in which are found small temporary or permanent lakes and larger areas in which stream or lake deposits of gravel, sand, and clay are spread over the eroded surfaces of older rocks." They continue by observing the lake basins, "are obviously not glacial features. The underlying rocks are of different ages, chiefly shale but partly sandstone. The basins can apparently not be explained as sinkholes due to solution and caving of underlying formations, and they cannot be adequately explained by wind erosion alone. There is evidence that they are due to warping and perhaps faulting in the rock formations that occurred in recent geologic times and may still be going on."

Alden (1932, p. 59) observes "the anomalous feature of these [lake] basins is that they are undrained-that is, their outlets are not deep enough to drain all of the nearly flat bottoms, so that they may formerly have been occupied by large lakes.... There is some question as to the conditions under which these basins were developed and as to how the material was removed to make them basins." Alden then suggests the basins may be the result of stream erosion when the Yellowstone River was flowing at a level 1,000 feet [305 meters] higher than present. If so, Alden suggests "Once started, the surrounding abrupt inclosing escarpments or rims would continue to recede under processes of planation," which Alden (p. 13) considers to be where springs and seeps undermine overlying bedrock layers and cause escarpment or cliff retreat. Alden (p. 24-25) further suggests valleys of the Yellowstone and Musselshell Rivers at that time "were broad shallow basins distinctly separated by a worn-down divide whose crest was not more than 700 or 800 feet [213 or 244 meters] above either of the streams" (which based on present-day elevations implies the Yellowstone River valley has since been lowered by about 100 meters with little or no deepening of the shallower Musselshell River valley). 
The above-mentioned investigators and others interpreted the Yellowstone and Musselshell River drainage systems to have originated during Tertiary time as north-oriented rivers which once flowed into Canada and which continental ice sheets blocked so as to form an ice-marginal Missouri River. Alden and others used what they interpreted to have been ice rafted glacial boulders extending upstream (from mapped ice sheet margins) in the north-oriented preglacial Musselshell and Yellowstone valleys as evidence ice-dammed lakes once filled those blocked north-oriented valleys. The glacial lakes are shown in Alden's (1932) Plate 1 and in a more recently prepared Colton et al (1961) map. Davis (2004) and Davis et al (2006) note the boulders for many years represented the only physical evidence associated with the lakes and that lake sediments, shorelines, and deltas at inflow points had not been identified. Alden and others suggested Glacial Lake Musselshell may have overflowed in one or more valleys located slightly to the east of this paper's figure 2, however Davis (2004) and Davis et al (2006) suggest the lake, which they date as having existed between 20 and $11.5 \mathrm{ka}$, was unstable and may not have reached a high enough level to drain south into the Yellowstone River valley.

While most published reports since Alden's (1932) professional paper have not addressed study region landforms a preglacial age for the north-oriented Musselshell and Yellowstone River drainage systems represents the most important accepted paradigm interpretation pertinent to this paper. In addition, the United States Geological Survey (USGS) has prepared and published detailed paradigm neutral topographic maps, which are available at the USGS National Map website and which provide critical evidence needed to determine erosional landform and drainage system origins (evidence which was not available to earlier workers). In addition, Montana Bureau of Mines and Geology geologic maps, published at a scale of 1:100,000, cover the study region and include the Porter and Wilde (1999), Vuke et al (2003), Vuke and Wilde (2004), and Wilde and Porter (2008) geologic maps. Further, satellite imagery available from multiple sources including the USGS National Map website is also available.

\subsection{Previous Work-New Paradigm}

To date, no published reports using a new paradigm perspective address the Musselshell-Yellowstone River drainage divide area, although research notes, which include notes on the Musselshell-Yellowstone River drainage divide area, written in blog format when this author (Clausen) used Missouri River drainage basin topographic map evidence to develop the new paradigm can be found at geomorphology research.com. As already noted, the Musselshell and Yellowstone Rivers are north-oriented Missouri River tributaries and unlike the accepted paradigm, which views the Musselshell and Yellowstone Rivers as preglacial drainage systems, the new paradigm considers the Musselshell and Yellowstone River drainage systems to have developed late during a large continental ice sheet's melt history. At that time north-oriented valleys eroded headward from the ice sheet location across massive southeast-oriented meltwater floods. This means the large ice sheet was located in a deep "hole" (which the ice sheet had created) and the north-oriented valleys diverted large ice-marginal meltwater floods into space the melting ice sheet had once occupied. This paradigm difference leads to a Cenozoic history incommensurable (using Kuhn's term) with the accepted paradigm Cenozoic history, which means the two Cenozoic histories are incompatible and cannot be easily compared.

What the new paradigm describes is a large (thick) continental ice sheet which was located approximately where North American continental ice sheets are usually considered to have existed. That large ice sheet created and then occupied a deep "hole." The deep "hole" was formed by deep continental ice sheet erosion and by ice sheet caused crustal warping. The crustal warping raised the Rocky Mountain region as massive and prolonged south-oriented meltwater floods flowed across it (including across the entire Missouri River drainage basin) with uplift gradually diverting the huge meltwater floods in southeast directions between the rising mountains and the melting ice sheet. As ice sheet melting opened up space (first at the deep "hole's" southern end) northeast- and north-oriented valleys eroded headward (in sequence beginning in the southeast and progressing to the northwest) from the newly opened up deep "hole" space to capture the ice-marginal meltwater floods and to divert the floodwaters into the deep "hole" space. At first diverted meltwater floods moved through the deep "hole" southern end to a south-oriented outlet in southcentral South Dakota near where the James River now joins the Missouri River. As ice sheet melting progressed the diverted ice-marginal meltwater floods flowed northward through ice-walled canyons across the ice sheet floor to reach northern outlets (which is why abandoned extensions of north-oriented Missouri River tributary valleys now continue across Canada). Diversion of meltwater floods in a north direction changed oceanic currents and the climate, which ended ice sheet melting and which caused the northoriented drainage to freeze around decaying ice sheet remnants so as to form a second and much thinner ice sheet. The Missouri River developed as an ice-marginal river along that second ice sheet's margin.

The new paradigm predicts the deep northeast-oriented Yellowstone River valley first eroded headward into this paper's study area (shown in figure 1) to capture immense southeast-oriented floods. If so, the northeast-oriented Yellowstone River valley segment should be joined by numerous southeast-oriented tributary valleys and even a southeast-oriented Yellowstone River segment (as seen in figures 1 and 2). In addition, numerous low points or divide crossings should be found along the Musselshell-Yellowstone River drainage divide showing where multiple and closely spaced streams of southeast-oriented meltwater (probably flowing in large anastomosing channel complexes) flowed across the region. The 
new paradigm also predicts the north- and northeast-oriented Musselshell River valley segments next eroded headward across the same massive southeast-oriented meltwater floods, which ended flood flow to the newly eroded Yellowstone River valley and which diverted floodwaters northward in the newly eroded Musselshell River valley. If so, Musselshell River valley headward erosion should have beheaded and reversed southeast-oriented flood flow channels crossing what is now the Musselshell-Yellowstone River drainage divide so as to create northwest-oriented barbed tributaries and should also be joined by southeast-oriented tributaries and by a southeast-oriented Musselshell River segment (all of which are also seen in figure 2).

\section{Research Method}

The study reported here used topographic map interpretation techniques with detailed topographic maps found at the USGS National Map website. For example, barbed tributaries were interpreted to be evidence of capture events involving reversals of flow on what had been an earlier drainage system (see Thornbury, 1969, p. 120). A valley joined by multiple closely spaced normal tributaries on one side and multiple closely spaced barbed tributaries on the other side was interpreted to have eroded headward across multiple closely spaced channels as might be found in a flood formed anastomosing channel complex. Low points along drainage divides (or divide crossings) were interpreted (unless there was reason to believe otherwise) to have been places where water once flowed in one direction or the other across the drainage divide. Barbed tributaries and the drainage divide symmetry were then used to interpret the probable direction of flow and closely spaced divide crossings were interpreted to have been eroded by multiple closely spaced channels such as might be found in flood formed anastomosing channel complexes. Based on interpretations made in other new paradigm demonstration papers for similar features (discussed below) large escarpment-surrounded and amphitheatershaped basins were interpreted to be large abandoned headcuts eroded by water moving in the direction in which the escarpment-surrounded basins now open. The goal was to apply simple and common sense-based map interpretation techniques to determine the erosional landform origins.

\section{Results}

\subsection{Analysis of the Well-Defined Musselshell-Yellowstone River Drainage Divide Segment}

The well-defined Musselshell-Yellowstone River drainage divide segment was followed on detailed topographic maps westward from about 10 kilometers east of figure 2 where previous investigators have suggested a divide crossing with a floor elevation of about 970 meters (between west-oriented Home Creek flowing to the Musselshell River and southsoutheast oriented Muggins Creek flowing to the Yellowstone River) had served as a Glacial Lake Musselshell outlet. Continuing westward in a west-southwest direction for about 75 kilometers (as the crow flies) along the drainage divide until Dunn Mountain was reached numerous other divide crossings were noted with some shown in table 1. Floor elevations shown are rounded to the nearest 5 meters and approximate depths are based on nearby drainage divide elevations, but for many of the listed divide crossings a case can be made for much greater depths by using more distant drainage divide elevations. Generally, table 1 divide crossings are oriented in northwest-southeast directions and are representative of other unlisted and shallower divide crossings which link the listed and other Musselshell and Yellowstone River tributary drainage basins. The divide crossing with the highest floor elevation was at Dunn Mountain and is seen in figure 3. Except for regions near the figure 2 western edge the highest elevations found anywhere along the study region Musselshell-Yellowstone River drainage divide are at Dunn Mountain.

The Rehder Coulee tributary-Pompeys Pillar Creek divide crossing is at location 1 in figure 3 and is approximately 425 meters higher than the Home Creek-Muggins Creek divide crossing yet both divide crossings and the divide crossings between them suggest headward erosion of the northeast- and north-oriented Musselshell River valley (and north-oriented tributary valleys from it) captured multiple streams of southeast-oriented water that had been flowing across what is now the Musselshell-Yellowstone River drainage divide. The divide crossing floor elevation differences are puzzling and may be partially explained by uplift of the Dunn Mountain area relative to regions further to the east and west, but more likely suggest much deeper erosion occurred in areas to the east and west of Dunn Mountain (which also suggests many divide crossing depths are much deeper than shown in table 1). Evidence seen in figure 3 is intriguing because the southwestand south-oriented divide crossings at locations 2, 3, and 4 are lower than the northwest-southeast oriented divide crossing at location 1 with the floor elevation being about 1395 meters at location 1, 1385 meters at location 2, 1355 meters at location 3, and 1335 meters at location 4. Southeast-oriented water flowing across location 1 was apparently captured in sequence as the deep south-oriented Razor Creek valley eroded headward into the region.

Figure 4 shows a larger area in less detail and illustrates how the figure 3 area (in red rectangle) is located on the northeastern rim of the Razor Creek escarpment-surrounded and amphitheater shaped basin. Note in figure 4 how multiple northwest-oriented tributaries to a north-oriented Musselshell Creek tributary (Goulding Creek) originate along the Razor Creek escarpment-surrounded basin northwest rim. Shallow divide crossings link the northwest-oriented Goulding Creek tributary valleys with southeast-oriented Razor Creek tributary valleys and have floor elevations in the 1250-meter range 
(approximately 100 meters lower than floor elevations of divide crossings seen in figure 3). While Ellis and Meinzer (1924) suggest several cycles of erosion were needed to erode the region it seems more probable large and prolonged volumes of southeast-oriented water eroded the large Razor Creek amphitheater-shaped basin. Further, such an explanation suggests the entire Musselshell-Yellowstone River drainage divide region was as high or higher than Dunn Mountain when the large and prolonged southeast-oriented floods began and the floodwaters moved in what must have been anastomosing channel complexes. Such floods must have carved the region to produce present-day elevations before headward erosion of the deeper northeast-oriented Musselshell River-Goulding Creek valley captured the southeastoriented floodwaters and diverted the water in a north direction with continuing Musselshell River valley (and another north-oriented Musselshell River tributary valley) headward erosion next capturing southeast-oriented flow to the Goulding Creek valley.

Table 1. Representative divide crossings from a short distance east of the study region to Dunn Mountain along the easy to identify Musselshell-Yellowstone River drainage divide segment showing floor elevations (rounded) and approximate depths based on nearby drainage divide elevations.

\begin{tabular}{llcc}
\hline Musselshell drainage & Yellowstone drainage & Floor elevation (m) & Approx. depth (m) \\
\hline Home Creek & Muggins Creek & 970 & 50 \\
Horse Ck trib. & N Fk. Alkali Ck trib. & 1075 & 50 \\
Lost Horse Ck & Indian Ck & 1020 & 30 \\
Lost Horse Ck & Cabin Ck & 1005 & 25 \\
Angus Bell Coulee & Alkali Ck & 1055 & 20 \\
Carpenter Ck & Alkali Ck & 1035 & 35 \\
Hawk Ck trib. & East Buffalo Ck & 1075 & 20 \\
Hawk Ck & Deadman Ck & 1050 & 20 \\
Dry Fk. Hawk Ck & Buffalo Ck & 1050 & 50 \\
Dry Fk. Hawk Ck & Cow Ck trib. & 1180 & 20 \\
Dry Fk. Hawk Ck & Cow Gulch & 1190 & 20 \\
Fattig Creek & Dutch Oven Creek & 1275 & 30 \\
Rehder Coulee trib. & Pompeys Pillar Creek & 1395 & 40 \\
\hline
\end{tabular}

\subsection{Analysis of the Hay Basin, Comanche Basin, and Lake Basin Area}

The well-defined Musselshell-Yellowstone River drainage divide segment after circling around the Razor Creek amphitheater-shaped basin northern rim reaches the relatively flat-floored Hay Basin area where the drainage divide location becomes blurred. The Hay Basin is a flat floored region of internal drainage with lower floor elevations in the 1175-meter range and is linked on the Yellowstone River side by shallow divide crossings across an asymmetric drainage divide leading down steep slopes into the Razor Creek and Hoskins Basins. To the north Hay Basin is linked by shallow divide crossings with northwest- and north-oriented Dean Creek, which joins the Musselshell River near the figure 4 top. Alden (1932) suggests basins like the Hay Basin (and Comanche and Lake Basins discussed in following paragraphs) were initially eroded by streams and then widened by cliff retreat, although the shallow divide crossings linking Hay Basin with southeast-oriented streams flowing into the much deeper Hoskins and Razor Creek Basins suggest large and prolonged sheet-like floods of southeast-oriented water must have flowed across the Hay Basin area with the much deeper escarpment-surrounded Hoskins and Razor Creek Basins being eroded headward into the Hay Basin floor until Musselshell River and Dean Creek valley headward erosion captured the southeast-oriented flood flow and ended erosion of the Hoskins and Razor Creek escarpment-surrounded basins. The shallow internal drainage basin areas may have formed when the sheet-like floods of water scoured less resistant bedrock areas slightly more deeply than the more resistant bedrock areas.

Southwest of Hay Basin the Musselshell-Yellowstone River drainage divide continues to be blurred as it crosses the northnorthwest to south-southeast oriented Comanche Basin. Like the Hay Basin the Comanche Basin is a relatively flatfloored region of internal drainage and with floor elevations in the 1140- to 1145-meter range (or about 30 meters lower than the Hay Basin floor elevations). The highway and railroad extending across Comanche Basin both make use of broad divide crossings located just north and south of figure 4 (the southern divide crossing is seen in figure 5). The northern divide crossing is approximately 50 meters deep and links the Comanche Basin with northeast-oriented Painted Robe Creek (which flows to the Musselshell River). The divide crossing to the south of the Comanche Basin is at least 6 kilometers wide and more than 50 meters deep. To the south of figure 4 the highway proceeds down a steep grade into the Yellowstone River valley to reach Billings (located just east of figure 5). The divide crossings and the Comanche 
Basin elongate shape suggest that prior to headward erosion of the northeast-oriented Musselshell River-Painted Robe Creek valley large volumes of south-southeast oriented water flowed through the Comanche Basin and as in the Hay Basin probably scoured less resistant bedrock areas deeper than more resistant bedrock areas. Headward erosion of the deep northeast-oriented Yellowstone River valley at some point captured the flow with southeast-oriented tributary valleys starting to erode headward into the Comanche Basin until headward erosion of the northeast-oriented Musselshell CreekPainted Robe Creek valley captured the southeast-oriented flood flow and diverted the water in a north direction.

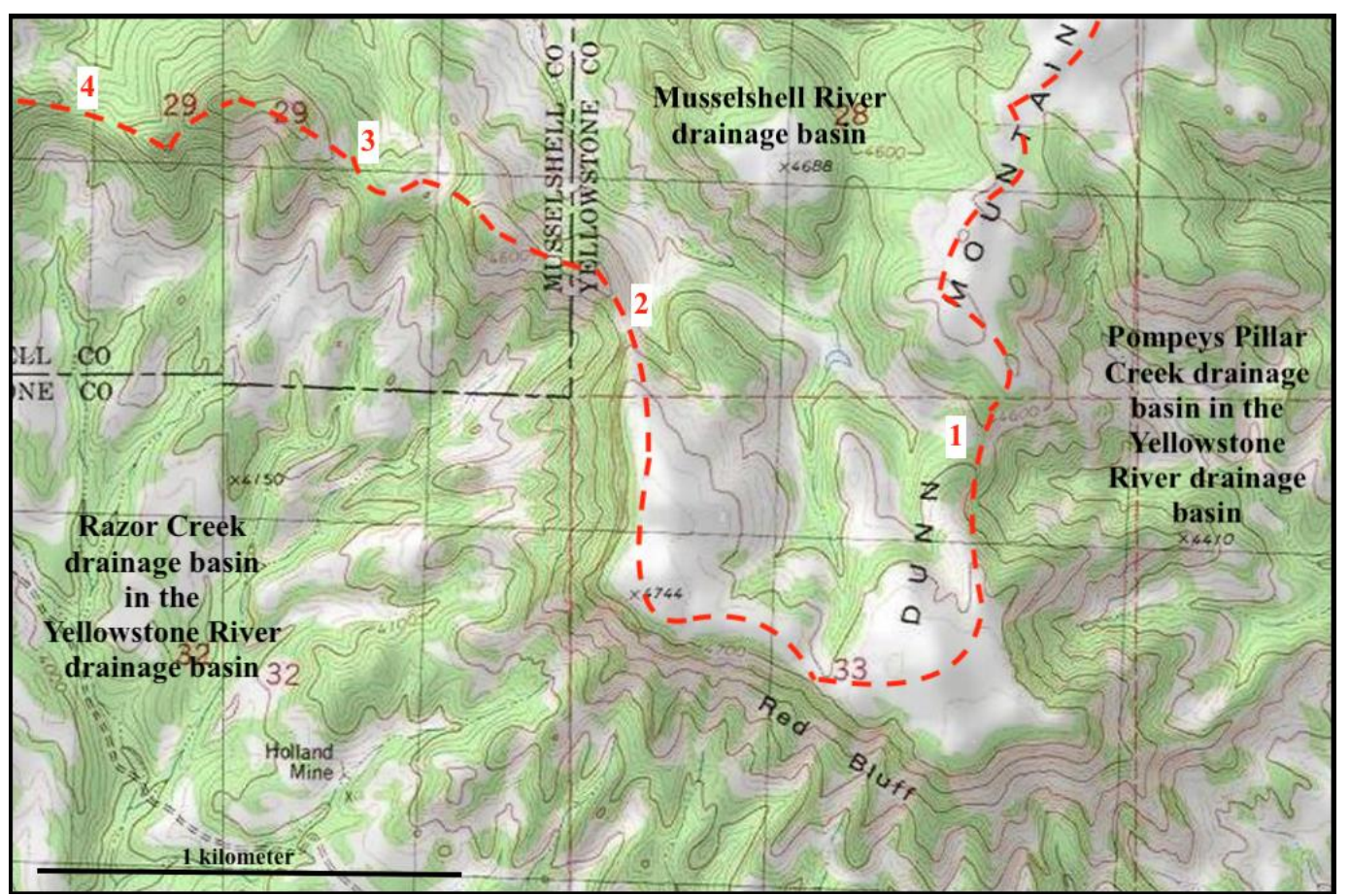

Figure 3. Modified detailed topographic map from USGS National Map website showing the easy to identify Musselshell-Yellowstone drainage divide (dashed red line) location in the Dunn Mountain area. Numbers identify

divide crossings (drainage divide low points) discussed in the text. Contour interval is 20 feet (6 meters).

West of the Comanche Basin (and of figure 4) the Musselshell-Yellowstone River drainage divide continues to be blurred as it crosses the large northwest- to southeast-oriented Lake Basin (seen in figure 5), which extends between northeastoriented Big Coulee headwaters (flowing to the Musselshell River and unseen in figure 5) and southwest and eastsoutheast oriented Canyon Creek (flowing to the Yellowstone River). Note in figure 5 how a large meander of the southeast-oriented Yellowstone River segment reaches into the southwest corner and a section of the northeast-oriented Yellowstone River segment is in the southeast corner. Lake Basin, like the Hay and Comanche Basins, is a relatively flatfloored internally drained region straddling the Musselshell-Yellowstone River drainage divide. The Lake Basin northwest to southeast orientation is similar to the southeast-oriented Yellowstone River segment orientation and to many Yellowstone and Musselshell River tributary orientations (see figure 2). Lake Basin floor elevations exceed 1200 meters and are slightly higher than in the Hay Basin where lowest floor elevations are slightly higher than in the Comanche Basin. At the Lake Basin northwest end a well-defined 75-meter deep and kilometer wide divide crossing links the northeastoriented South Fork Big Coulee valley with internal drainage routes leading to lakes within Lake Basin. A broader and deeper divide crossing links Lake Basin with the Yellowstone River valley (now drained by Canyon Creek southwestoriented headwaters) and suggests large volumes of southeast-oriented water once flowed from Lake Basin into the Yellowstone River valley. Headward erosion of the Musselshell River and Big Coulee valleys captured southeast-oriented flow that had been moving across the Lake Basin floor and diverted the water northward.

\subsection{Hoskins and Razor Creek Escarpment-Surrounded and Amphitheater Shaped Basins}

The large amphitheater-shaped and escarpment-surrounded Hoskins and Razor Creek Basins are unusual by their semicircular escarpment rims and large sizes. Hoskins Basin is drained by southeast-oriented Crooked Creek which flows to the northeast-oriented Yellowstone River. The Razor Creek Basin is now drained by south- and southeast-oriented Razor Creek, but study of drainage routes suggests south-oriented Razor Creek valley headward erosion beheaded and captured what was once a southeast-oriented tributary to south- and southeast-oriented Pompeys Pillar Creek (which also flows to the northeast-oriented Yellowstone River). The two adjacent basins are erosional features and their erosion must have required immense volumes of what must have been southeast-oriented water. The water must have come from northwest 
of what is today the northeast-oriented Musselshell River valley and figure 2 suggests headward erosion of the northeastoriented Musselshell River valley segment must have captured the vast volumes of southeast-oriented flow that had been moving to the Hoskins and Razor Creek Basins. In a sense the two amphitheater-shaped basins can be considered large and abandoned headcuts, which had been eroded headward from the deep Yellowstone River valley in northwest and north directions and which were abandoned when Musselshell River valley headward erosion captured the southeastoriented flood flow and diverted the floodwaters in a north direction.

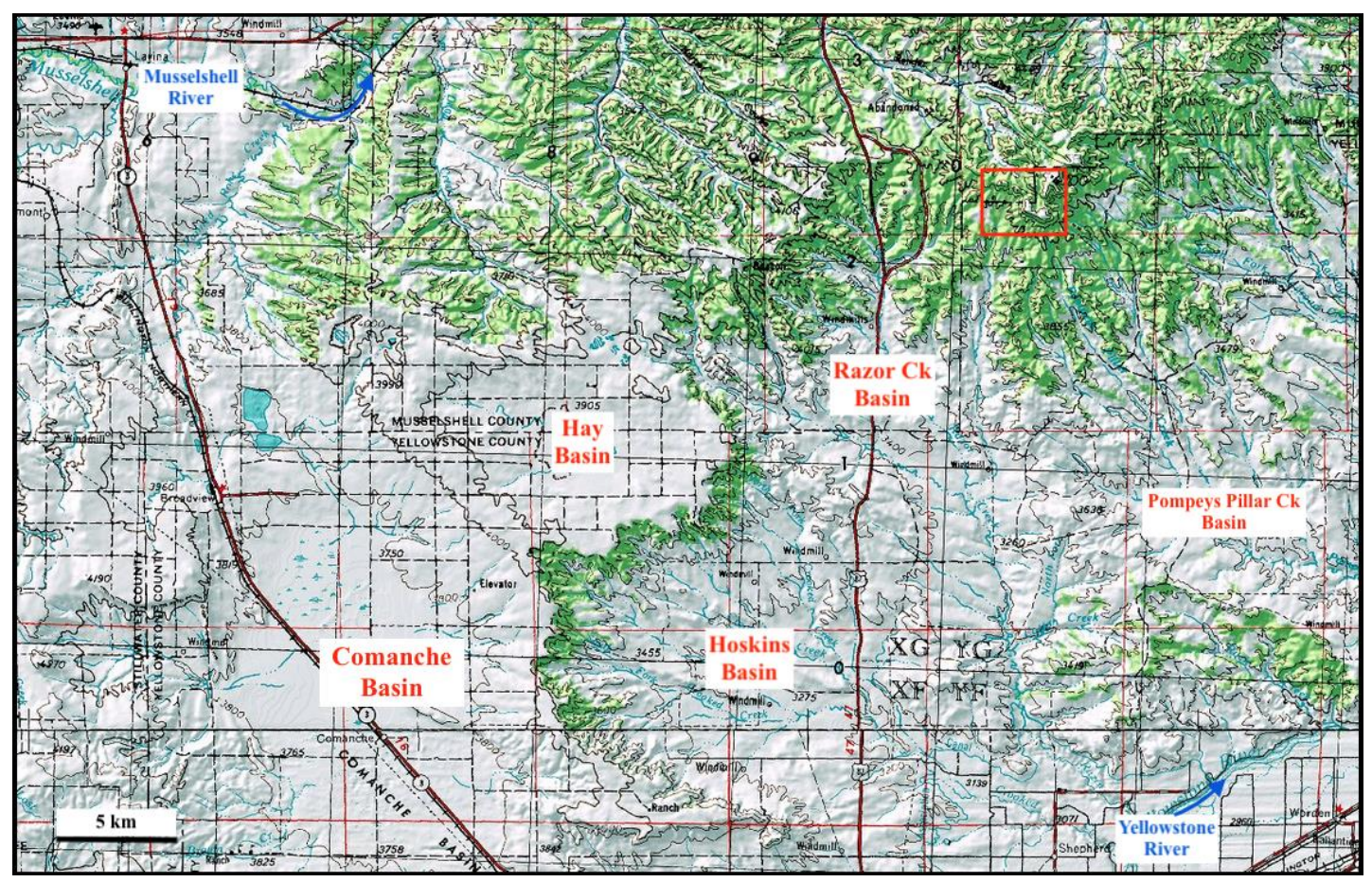

Figure 4. Modified topographic map from USGS National Map website showing Musselshell-Yellowstone River drainage divide area. Red rectangle identifies the figure 3 (Dunn Mountain) location. Contour interval is 200 feet (61 meters).

The author of this paper (Clausen) has described a number of other Great Plains and Rocky Mountain region amphitheatershaped and escarpment-surrounded basins which are similar in shape, orientation, and size to the Hoskins and Razor Creek Basins. For example, Clausen (2018, p. 49-51) discusses the Goshen Hole Basin, which straddles the WyomingNebraska border and cites three other papers describing the Scenic and Sage Creek Basins east of the South Dakota Black Hills, the Jump-Off escarpment-surrounded basin in northwest South Dakota, and the Russian Springs Escarpment (west end) in western North Dakota. In each case the large semi-circular escarpment-surrounded basins suggest erosion by huge volumes of southeast- or east-oriented water, but in each case a north-oriented valley is located immediately west of the escarpment-surrounded basin. From the accepted paradigm perspective those north-oriented valleys predate the escarpment-surrounded basins, meaning large volumes of southeast- or east-oriented water could not have reached the large escarpment-surrounded basins. For this reason, previous workers rarely explain how the large escarpmentsurrounded basins originated or explain the basin development by seepage-induced cliff recession as discussed in Higgins (1990). From the new paradigm perspective, valleys (north and west the large escarpment-surrounded basins) eroded headward across large southeast- or east-oriented floods to capture the floodwaters that had been eroding the escarpmentsurrounded basins headward (as large headcuts) and then left the semi-circular basins as abandoned headcuts.

\section{Discussion}

Detailed topographic maps show numerous low points or divide crossings along the study region Musselshell-Yellowstone River drainage divide. Both paradigms describe each divide crossing as an erosional feature formed when water moved across what is now the drainage divide, although the accepted paradigm view is the erosion took place during Tertiary time while the new paradigm view is southeast-oriented and ice-marginal meltwater floods eroded the region. The divide crossings link southeast- and south-oriented Yellowstone River tributary valleys with north-oriented Musselshell River tributary valleys and (except divide crossings at locations 2, 3, and 4 in figure 3) are mostly oriented in northwest to southeast directions. Previous workers suggested the lowest elevation divide crossings may have served as Glacial Lake Musselshell outlets, although the higher elevation divide crossings have been left unexplained. Divide crossing floor elevations included in table 1 range from 970 meters to 1395 meters while divide crossings associated with the Hay, 
Comanche, and Lake Basins range from 1140 meters to more than 1200 meters. Based on present-day elevations each divide crossing was eroded by southeast-oriented streams of water moving toward the northeast-oriented Yellowstone River valley. A major southeast-oriented drainage system, which must have once flowed on a surface equivalent to the highest Dunn Mountain elevations today, flowed across and deeply eroded the region prior to headward erosion of the northeast- and north-oriented Musselshell River valley.

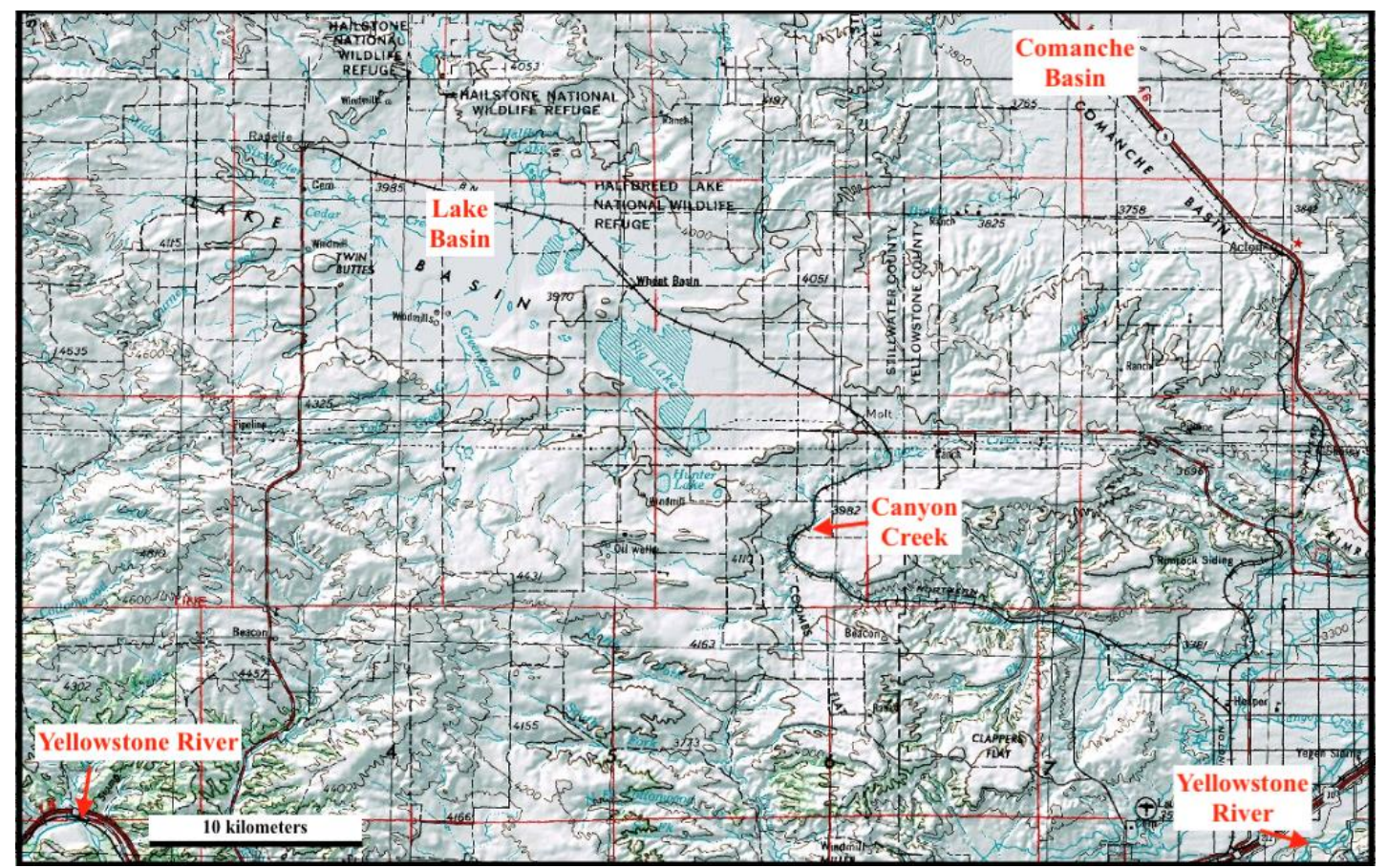

Figure 5. Modified topographic map from USGS National Map website showing location of Lake Basin relative to Comanche Basin, Canyon Creek, and the Yellowstone River. Contour interval is 200 feet (61 meters).

Assuming the southeast-oriented drainage system developed on what was probably a low relief surface, which sloped gently in an eastward direction and which in the study region was as high or higher than the Dunn Mountain top the southeast-oriented drainage system was first captured by headward erosion of the deep northeast-oriented Yellowstone River valley and then flowed to the newly eroded Yellowstone River valley until Musselshell River valley headward erosion created the Musselshell-Yellowstone River drainage divide. Because immense volumes of water were needed to remove hundreds of meters of sediments from Musselshell-Yellowstone River drainage divide areas the accepted paradigm needs extremely long periods of time to account for the erosion while the new paradigm's massive southeastoriented meltwater floods could have eroded the region in a much shorter time period. This paper has not addressed Yellowstone River valley evidence and history, although it is reasonable to assume headward erosion of the deep northeast-oriented Yellowstone River valley diverted what had been southeast-oriented drainage in a northeast direction. The large Hoskins and Razor Creek escarpment-surrounded basins suggest massive amounts of southeast-oriented drainage continued after the Yellowstone River valley capture and before Musselshell River valley headward erosion. Southeast-oriented tributaries flowing to the northeast-oriented Yellowstone and Musselshell River segments and upstream southeast-oriented Yellowstone and Musselshell River segments (seen in figure 2) document the previous and extensive southeast-oriented drainage system.

The question then arises, why don't previous investigators discuss this previous southeast-oriented drainage system? For example, in both Davis (2004) and Davis et al (2006) no mention is made of the fact (seen in figures 1 and 2) that the Musselshell River flows in southeast and northeast directions before turning in a north direction and is instead described as flowing in an east direction prior to its northward turn, however that error does not affect the conclusions that Glacial Lake Musselshell was unstable, existed from about 20 to $11.5 \mathrm{ka}$, and may not have been high enough to spill over the Musselshell-Yellowstone River drainage divide. Much other regional geomorphic work relies on USGS work done approximately one hundred years ago at a time when detailed topographic maps were not available. At that time Alden (who did field work for his 1932 Professional Paper during the 1920s) supervised USGS geomorphology research and approved all USGS geomorphology related publications and Meinzer (who did work described in Ellis and Meinzer, 1924) was responsible for USGS ground water research and publications and all USGS interpretations of the MusselshellYellowstone River drainage divide area geomorphic history had to meet with either Alden's or Meinzer's approval. 
While Alden was doing field work leading to his Musselshell-Yellowstone River drainage divide area interpretations and shortly after the Ellis and Meinzer publication (written by Meinzer following the death of Ellis) J Harlen Bretz was publishing results of his then on-going eastern Washington Channeled Scabland investigations in which he argued an immense flood had flowed across what are now major drainage divides (e. g. Bretz, 1923, 1925). At that time Bretz was exploring how large ice sheets might generate giant floods and no flood source had been identified. USGS geologists invited Bretz to present his flood evidence on January 12, 1927 at the Cosmos Club in Washington, DC. The meeting transcript (Bretz, 1927) includes comments made by Alden and Meinzer. Alden points out while he had not worked in the Channeled Scablands, he had read Bretz's published papers with great interest and then objected to the Bretz flood hypothesis. Meinzer, who had done some work in the Channeled Scabland region, but not in all areas Bretz described, also raised objections to the Bretz flood hypothesis.

Whether Alden's and Meinzer's objections were related to their interpretation of the Musselshell-Yellowstone River drainage divide evidence which must have been fresh in their minds is difficult to determine. However, the question can be asked, why didn't Meinzer and especially Alden (who's 1932 professional paper was published after the 1927 meeting) when interpreting their Musselshell-Yellowstone River drainage divide area evidence consider a hypothesis involving large southeast-oriented ice-marginal floods similar to what Bretz was proposing? T. C. Chamberlin (1897) in a paper (required reading for many early $20^{\text {th }}$ century geology students) urged geologists to use the method of multiple working hypotheses in which Chamberlin argues when only one hypothesis is considered that hypothesis can easily become a ruling theory and blind a geologist's thinking to other and perhaps better explanations. Instead, Chamberlin encourages geologists to consider and test all possible hypotheses. Bretz was proposing a hypothesis that could reasonably be applied to the Musselshell-Yellowstone River drainage divide area, yet Alden did not consider and test a Bretz type flood hypothesis.

What ruling theory blinded Alden's thinking so as to prevent him from considering the possibility that large southeastoriented ice-marginal meltwater floods might have once flowed across the Musselshell-Yellowstone River drainage divide? Probably that ruling theory was the then (and still) accepted paradigm interpretation in which the north-oriented Missouri River headwaters, Musselshell River, and Yellowstone River (among other north-oriented drainage routes) originated during Tertiary time as components of a north-oriented drainage system which Pleistocene continental ice sheets blocked to form the ice-marginal Missouri River (which is now the Missouri River downstream from where it turns from flowing in a north direction to flow in an east and then southeast direction). With that ruling theory in his mind Alden apparently did not consider large southeast-oriented ice-marginal meltwater floods for erosion of the unusual lake basins discussed in his publication nor did he apparently consider the possibility that large southeast-oriented meltwater floods were responsible for the deep regional erosion discussed in his 1932 publication and in earlier USGS publications or for the deposition of gravels and other alluvium which his 1932 and other earlier USGS publications describe.

While Alden's thoughts are not known he was definitely aware the Musselshell-Yellowstone River drainage divide is near a former continental ice sheet margin and meltwater floods could have flowed in a southeast direction across it. Yet accepted paradigm interpretations required (and still require) the Musselshell River to predate any North American (Cenozoic) continental ice sheets, which in Alden's mind would have made it impossible for meltwater floods to flow across the preglacial north-oriented Musselshell River valley unless the ice sheet blocked the valley to form an icedammed lake (Glacial Lake Musselshell), which Alden did propose. Alden did see Glacial Lake Musselshell rising high enough so water spilled across the Musselshell-Yellowstone River drainage divide at locations just east of this paper's figure 2 (e. g. the Home Creek-Muggins Creek divide crossing in table 1) at elevations much lower than at the divide crossings further to the west such as in the Dunn Mountain and Hay, Comanche, and Lake Basin areas. Adherence to the then (and still) accepted paradigm requirement in which a north-oriented drainage system developed during Tertiary time as Rocky Mountain uplift and middle and late Tertiary sediment deposition occurred prevented Alden from suggesting large meltwater floods once flowed across the Musselshell-Yellowstone River drainage divide.

When interpreting Musselshell-Yellowstone River drainage divide area erosional landform evidence the accepted paradigm did not provide an adequate water source to explain evidence Alden described and also other erosional landforms he probably saw but for whatever reason did not discuss. As a result, Alden admitted to not knowing how some described erosional landforms originated, such as in the above quoted description of the lake basins (which include the Hay, Comanche, and Lake Basins) and he ignored other erosional landform features such as the large escarpmentsurrounded Hoskins and Razor Creek Basins. Without saying so, Alden described anomalous evidence, which he probably hoped (after good quality topographic maps became available) future geomorphologists would explain. Unfortunately, even though excellent topographic maps are now available the accepted paradigm leaves today's geomorphologists in the same quandary. As this paper demonstrates detailed topographic map evidence in the Musselshell-Yellowstone River drainage divide area can be explained by large southeast-oriented floods, which headward erosion of the northeastoriented Musselshell River captured and diverted in a north direction. But the accepted paradigm requires those events to 
have occurred prior to any North American (Cenozoic) continental ice sheets, which for Alden eliminated large icemarginal meltwater floods as the probable water source.

The Musselshell-Yellowstone River drainage divide area anomalous evidence is just the tip of the iceberg of a much larger anomalous evidence problem the geological research community must address. Early $20^{\text {th }}$ USGS geologists like Alden and Meinzer lacked access to good quality topographic maps, although at that time there was an expectation such maps when available would enhance the geomorphology research community's ability to interpret erosional landform origins. Today such maps exist, but the geomorphology research community is not using those maps to interpret erosional landform origins. By the mid $20^{\text {th }}$ century geomorphologists learned the accepted Cenozoic geologic and glacial history paradigm does not permit erosional landforms to be explained. For example, Strahler (1945 and 1952) after attempting to explain Pennsylvania erosional landforms concluded trying to do so was a nonproductive research activity and developed a dynamic basis for geomorphology. Without saying so Strahler and other geomorphologists determined most erosional landforms cannot be interpreted in ways consistent with the accepted paradigm expectations. As a result, since the mid $20^{\text {th }}$ century the geology literature has rarely included research related to erosional landform origins and the tens of thousands of excellent USGS prepared detailed topographic maps now represent a vast warehouse of well mapped and unexplained anomalous erosional landform evidence.

\section{Conclusions}

Southeast-oriented tributaries flowing to northeast-oriented Musselshell River and Yellowstone River segments, Musselshell River and Yellowstone River southeast-oriented segments which are immediately upstream from northeastoriented Musselshell and Yellowstone River segments, and numerous divide crossings along the Musselshell-Yellowstone River drainage divide can be explained if headward erosion of the northeast-oriented Yellowstone River valley and of the northeast- and north-oriented Musselshell River valley were across a preexisting southeast-oriented drainage system with the Musselshell-Yellowstone River drainage divide being created when headward erosion of the northeast- and northoriented Musselshell River valley captured southeast-oriented flow that had been moving into the previously eroded northeast-oriented and deep Yellowstone River valley. Divide crossing floor elevations, headward erosion of the northeastoriented Yellowstone and Musselshell River valleys, the large Hoskins and Razor Creek escarpment-surrounded and amphitheater-shaped basins, and the extensive and relatively flat-floored internally drained basins (Hay, Comanche, and Lake Basins) now straddling the drainage divide can be explained if immense volumes of southeast-oriented water deeply eroded the region. These events are difficult to explain unless southeast-oriented ice-marginal floods flowed across the region (as the new paradigm predicts and the accepted paradigm denies).

Previous investigators working from the accepted paradigm perspective assumed the Musselshell and Yellowstone Rivers developed during Tertiary time, which requires Rocky Mountain uplift to have occurred and middle and late Tertiary sediments to have been deposited prior to any large North American continental ice sheets, and have implied the regional erosional landforms reflect the work of several (Tertiary) erosion cycles, but have not described in detail or offered explanations for most observed (on detailed topographic maps) erosional landforms. The accepted paradigm does not offer an adequate water source to account for the Musselshell-Yellowstone River drainage divide erosional landform features this paper describes. The new paradigm in which the north-oriented Yellowstone River valley eroded headward from a melting continental ice sheet across large southeast-oriented ice-marginal meltwater floods and the north-oriented Musselshell River valley next eroded headward across the same southeast-oriented ice-marginal floods explains most if not all observed Musselshell-Yellowstone River drainage divide area erosional landforms, although it leads to a Cenozoic geologic and glacial history that is incompatible with the commonly accepted Cenozoic geologic and glacial history.

\section{Acknowledgements}

Preliminary work leading up to new paradigm development was done while employed as a faculty member at Minot State University where other faculty members, students, and library staff assisted with access to the large number of the needed hard copy topographic maps. Arthur Strahler then at Columbia University and Brainerd Mears, Jr. then at the University of Wyoming (during the 1960s) introduced the author to numerous unsolved drainage history problems.

\section{References}

Alden, W. C. (1932). Physiography and glacial geology of eastern Montana and adjacent areas. United States Geological Survey Professional Paper, 174, 133. https://doi.org/10.3133/pp174

Bowen, C. F. (1919). Anticlines in a part of the Musselshell Valley, Musselshell, Meagher, and Sweet Grass Counties, Montana. United States Geological Survey Bulletin, 691, 190. https://doi.org/10.3133/b691f

Bretz, J. H. (1923). The Channeled Scablands of the Columbia Plateau. Journal of Geology, 31, 617-649. https://doi.org/10.1086/623053

Bretz, J. H. (1925). The Spokane flood beyond the Channeled Scablands. Journal of Geology, 33, 97-115, 236-259. 
https://doi.org/10.1086/623179

Bretz, J. H. (1927). Channeled Scabland and the Spokane Flood. Washington Academy of Science, 17(8), 200-211.

Chamberlin, T. C. (1890). The method of multiple working hypotheses. The Journal of Geology, 5(8), 837-848. https://www.jstor.org/stable/30054868

Clausen, E. (2018). Topographic map analysis of Laramie Range bedrock-walled canyon complex and the Goshen Hole escarpment-surrounded basin, Albany and Platte Counties, southeast Wyoming, USA. Open Journal of Geology, 8, 33-55. https://doi.org/10.4236/ojg.2018.81003

Clausen, E. (2020). Analyzing anomalous topographic map drainage system and landform evidence as a glacial history paradigm problem: a literature review. Open Journal of Geology, 10(11), 1072-1090. https://doi.org/10.4236/ojg.2020.1011052

Colton, R. B., Lemke, R. W., \& Lindvall, R. M. (1961). Glacial Map of Montana East of the Rocky Mountains: United States Geological Survey Miscellaneous Investigations Series Map I-327, scale 1:500,000. https://doi.org/10.3133/i327

Davis, N. K. (2004). Extent and Timing of Laurentide Glacial Lake Musselshell, Central Montana (Masters' Thesis, Montana State University, Bozeman, Montana), 202p. https://doi.org/10.5962/bhl.title.77295

Davis, N. K., Locke III, W. W., Pierce, K. L., \& Finkel, R. C. (2006). Glacial Lake Musselshell: Late Wisconsin slackwater on the Laurentide ice margin in central Montana, USA. Geomorphology, 75, 330-345. https://doi.org/10.1016/j.geomorph.2005.07.021

Ellis, A. J., \& Meinzer, O. E. (1924). Ground water in Musselshell and Golden Valley Counties, Montana. United States Geological Survey Water Supply Paper, 518, 92. https://doi.org/10.3133/wsp518

Hancock, E. T. (1918). Geology and oil and gas prospects of the Lake Basin field, Montana. United States Geological Survey Bulletin 691-D, 101-147.

Higgins, C. G. (1990). Seepage-Induced Cliff Recession and Regional Denudation. In: Higgins, C.G. and Coates, D.B., Eds., Groundwater Geomorphology: The Role of Subsurface Water in Earth-Surface Processes and Landforms, Geological Society of America Special Paper, 252, Boulder, 291-318. https://doi.org/10.1130/spe252-p291

Kuhn, T. S. (1970). The Structure of Scientific Revolutions, second edition, enlarged. The University of Chicago Press, Chicago, 210.

Porter, K. W., \& Wilde, E. M. (1999). Geologic map of the Musselshell 30' x 60' quadrangle. Montana Bureau of Mines and Geology Open-File Reports MBMG-386, scale 1:100,000.

Strahler, A. N. (1945). Hypotheses of stream development in the folded Appalachians of Pennsylvania. Geological Society of America Bulletin, 56, 45-88. https://doi.org/10.1130/0016-7606(1945)56[45:hosdit]2.0.co;2

Strahler, A. N. (1952). Dynamic basis of geomorphology. Bulletin of the Geological Society of America, 63, 923-938. https://doi.org/10.1130/0016-7606(1952)63[923:dbog]2.0.co;2

Thornbury, W. D. (1969). Principles of Geomorphology, second edition. John Wiley and Sons, New York. 594.

Vuke, S. M., Wilde, E. M., \& Bergantino, R. N. (2003). Geologic Map of the Hysham 30' x 60' quadrangle, eastern Montana. Montana Bureau of Mines and Geology Open-File Reports MBMG-486.

Vuke, S. M., \& Wilde, E. M. (2004). Geologic Map of the Melstone 30' x 60' Quadrangle, eastern Montana: Montana Bureau of Mines and Geology Open-File Report MBMG-513. https://doi.org/10.3133/ofr20061329

Wilde, E. M., \& Porter, K. W. (2008). Geologic map of the Roundup 30'x 60' quadrangle, central Montana, revised 2008. Montana Bureau of Mines and Geology Open-File Reports MBMG-404.

Woolsey, L. H., Richards, R. W., \& Lupton, C. T. (1917). The Bull Mountain coal field, Musselshell and Yellowstone Counties, Montana. United States Geological Survey Bulletin, 647, 218. https://doi.org/10.3133/b647

\section{Copyrights}

Copyright for this article is retained by the author(s), with first publication rights granted to the journal.

This is an open-access article distributed under the terms and conditions of the Creative Commons Attribution license (http://creativecommons.org/licenses/by/4.0/). 